\title{
Transition Metal Complexes of Quinolino[3,2-b]benzodiazepine and Quinolino[3,2-b]benzoxazepine: Synthesis, Characterization, and Antimicrobial Studies
}

\author{
B. Basavaraju, ${ }^{1}$ Halehatty S. Bhojya Naik, ${ }^{2}$ and Mustur C. Prabhakara ${ }^{2}$ \\ ${ }^{1}$ Department of Biotechnology, GM Institute of Technology, Davangere 577 006, Karnataka, India \\ ${ }^{2}$ Department of PG Studies and Research in Industrial Chemistry, School of Chemical Sciences, \\ Kuvempu University, Shankaraghatta 577 451, Shimoga, Karnataka, India
}

Received 7 August 2006; Revised 11 March 2007; Accepted 14 May 2007

Recommended by Ming Yang

The synthesis and characterization of title complexes of the ligand Quinolino[3,2-b]benzodiazepine (QBD) and Quinolino[3,2b]benzoxazepine (QBO) are reported. The complexes have been characterized by elemental analysis, molar conductance, magnetic studies, IR, ${ }^{1} \mathrm{H} \mathrm{NMR}$, and UV-visible studies. They have the stoichiometry $\left[\mathrm{ML}_{2} \mathrm{Cl}_{2}\right]$, where $\mathrm{M}=\mathrm{Co}(\mathrm{II}) / \mathrm{Ni}(\mathrm{II}), \mathrm{L}=\mathrm{QBD} / \mathrm{QBO}$, and $\left[\mathrm{MLCl}_{2}\right]$, where $\mathrm{M}=\mathrm{Zn}(\mathrm{II}) / \mathrm{Cd}(\mathrm{II}), \mathrm{L}=\mathrm{QBD} / \mathrm{QBO}$. The antibacterial and antifungal activity of the metal complexes has been investigated. The complexes were found to have higher antimicrobial activity than the parent ligand.

Copyright (c) 2007 B. Basavaraju et al. This is an open access article distributed under the Creative Commons Attribution License, which permits unrestricted use, distribution, and reproduction in any medium, provided the original work is properly cited.

\section{INTRODUCTION}

Quinoline derivatives represent the major class of heterocycles, and a number of preparations have been known since the late 1980s. The quinoline skeleton is often used for the design of many synthetic compounds with diverse pharmacological properties. Dynemicin A and Streptonigrin are naturally occurring members of the class of antitumor antibiotics, whose syntheses are based on the utilization of preformed quinoline derivatives [1]. The 8-(diethylaminohexylamino)6-methoxy-4-methyl-quinoline is highly effective against the protozoan parasite Trypanosoma cruzi, which is the agent of Chagas disease [2] and the 2-(2-methylquinolin-4-ylamino)$\mathrm{N}$-phenylacetamide is more active than the standard antileishmanial drug sodium antimony gluconate [3]. The centipede, Scolopendra Subspinipes mutilalns L. KOCH, which is found to contain 3,8-dihydroxyquinoline called Jineol has been prescribed for tetanus and childhood convulsions [4]. This drug has also been used for many other clinical purposes, such as the treatment of acute heart attack and as a toxicide in Korea [5]. Cryptolepine (5-methyl-5Hindolol[3,2-b]quinoline)-major Cryptolepis sanguinolenta alkaloid displays a plenty of pharmacological effects, such as antimuscarinic, noradrenergic receptor antagonistic, anti- hypertensive, vasodilative, antithrombotic, antipyretic, and anti-inflammatory properties. Neocryptolepine and cryptolepine derivatives reveal antiplasmodial, antitrypanosomal, and first of all, cytotoxic activities [6-8]. Quinoline containing drugs, particularly 4 -aminoquinolines, have a long and successful history as antimalarials $[9,10]$.

\section{MATERIALS AND METHODS}

\subsection{Analytical methods}

All the chemicals used in the present study are of AR grade. 2-Chloro-3-quinolinecarbaldehyde (Sigma-Aldrich Chemie, Germany), 2-aminophenol (S.D. Fine Chem Ltd, India), and $o$-Phenylenediammine (S.D. Fine Chem Ltd, India) were used. The metal contents of the complexes were determined by complexometric titrations and gravimetric estimations. The molar conductivities in $\operatorname{DMF}\left(10^{-3} \mathrm{M}\right)$ at room temperature were measured using an Equiptronics digital conductivity meter. Magnetic susceptibilities of the solid complexes were measured employing Gouy balance at room temperature $\left(28 \pm 2^{\circ} \mathrm{C}\right)$ using $\mathrm{Hg}\left[\mathrm{Co}(\mathrm{CNS})_{4}\right]$, that is, mercury(II) tetrathiocyanato cobaltate(II), as a calibrant for standardizing the Gouy tube. 


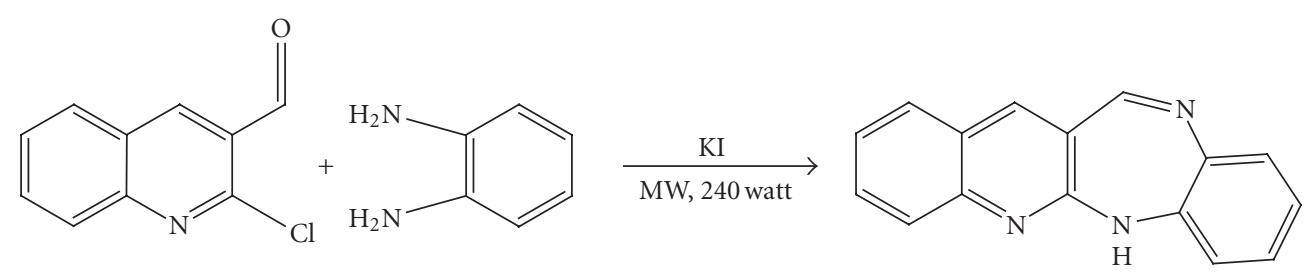

Quinolino[3,2-b]benzodiazepine

Scheme 1: Preparation of Quinolino[3,2-b]benzodiazepine(QBD).<smiles>Nc1ccc(-c2ccccc2)cc1O</smiles>

SCheme 2: Preparation of Quinolino[3,2-b]benzoxazepine(QBO).

\subsection{Spectral measurements}

The IR spectra of ligand and its metal complexes were recorded on a Shimadzu FTIR-8400S spectrometer with $\mathrm{KBr}$ pellets in the region $250-4000 \mathrm{~cm}^{-1}$. JEOL $60 \mathrm{MHz}$ spectrometer was used for recording the proton NMR spectra employing TMS as internal reference and DMSO- $\mathrm{d}_{6}$ as solvent. UV-visible spectra were measured on a Shimadzu double beam spectrophotometer using N,N'-dimethylformamide as a solvent at $10^{-3} \mathrm{M}$ concentration.

\section{EXPERIMENTAL}

\subsection{Synthesis of ligand QBD by microwave irradiation}

2-Chloro-3-quinolinecarbaldehyde $(0.958 \mathrm{~g}, 5 \mathrm{mmol})$ dissolved in small amount of acetic acid was taken in a $100 \mathrm{ml}$ borosil beaker. $o$-Phenylenediammine $(0.541 \mathrm{~g}, 5 \mathrm{mmol})$ and a pinch of potassium iodide were then added. The mixture was irradiated in a microwave oven for about $10 \mathrm{~min}$ utes. The product obtained was poured into ice-cold water, the solid separated was filtered, dried, and recrystallized (Scheme 1).

\subsection{Synthesis of ligand QBO by microwave irradiation}

Mixture of 2-aminophenol (0.11 g, $1 \mathrm{mmol}), \mathrm{KOH}(0.057 \mathrm{~g}$, $1 \mathrm{mmol}$ ), and $2 \mathrm{ml}$ of DMSO were taken in a $100 \mathrm{ml}$ borosil beaker. 2-Chloro-3-quinolinecarbaldehyde ( $1 \mathrm{mmol}$, $0.192 \mathrm{~g}$ ) and a pinch of KI were then added. The mixture was irradiated for about two minutes in a microwave oven. The product obtained was then hydrolyzed by pouring into icecold water. The final product separated as a solid on acidification with dilute $\mathrm{HCl}$ was then filtered and dried (Scheme 2).

\subsection{Synthesis of Cobalt(II) and Nickel(II) complexes of $Q B D$ and $Q B O$}

The ligand $(10 \mathrm{mmol})$ was dissolved in a dry methanol $(50 \mathrm{ml})$. A solution of the metal chloride $(5 \mathrm{mmol})$ in methanol $(50 \mathrm{ml})$ was then added dropwise to the ligand solution under nitrogen gas with continuous stirring. The mixture was refluxed for about 5 hours. The resulting precipitate was filtered off and washed with methanol. The precipitate was redissolved in ethanol on a water bath and the ethanol was slowly evaporated. Further, slow evaporation of the solution at room temperature resulted in the formation of colored compound.

\subsection{Synthesis of Cadmium(II) and Zinc(II) complexes of QBD and QBO}

The ethanolic solution of a ligand $(0.5 \mathrm{mmol})$ was slowly added to a $50 \mathrm{ml}$ solution of metal chloride $(0.5 \mathrm{mmol})$ in ethanol with continuous stirring. The reaction mixture was warmed on a water bath at 70 to $80^{\circ} \mathrm{C}$ for about 1 hour. The precipitate obtained was filtered, washed several times with absolute alcohol, finally with ether, and then dried over fused $\mathrm{CaCl}_{2}$.

\section{RESULTS AND DISCUSSION}

The complexes are microcrystalline colored powder, stable at room temperature, and are soluble in DMF and DMSO. The elemental analyses were satisfactory, show that the complexes have a ligand to metal ratio of $1: 2$ and $1: 1$, and have the general formula $\left[\mathrm{ML}_{2} \mathrm{Cl}_{2}\right]$, where $\mathrm{M}=\mathrm{Co}(\mathrm{II})$ or $\mathrm{Ni}(\mathrm{II})$, and $\left[\mathrm{MLCl}_{2}\right]$, where $\mathrm{M}=\mathrm{Zn}(\mathrm{II})$ or $\mathrm{Cd}(\mathrm{II}) ; \mathrm{L}=\mathrm{QBD}$ or $\mathrm{QBO}$. The molar conductance value (13.31-25.2 mhos $\left.\mathrm{cm}^{2} \mathrm{~mol}^{-1}\right)$ indicates the nonelectrolytic nature of the complexes (Table 1). 
TABLe 1: Analytical and physical data (calculated values are in parentheses).

\begin{tabular}{|c|c|c|c|c|c|c|c|c|c|}
\hline \multirow[t]{2}{*}{ Compound } & \multirow{2}{*}{$\begin{array}{l}\text { Yield } \\
(\%)\end{array}$} & \multicolumn{5}{|c|}{ Found (Calcd) (\%) } & \multirow{2}{*}{$\begin{array}{l}\text { Molar } \\
\text { conductiv- } \\
\text { ity mhos } \\
\mathrm{cm}^{2} \mathrm{~mol}^{-1}\end{array}$} & \multirow{2}{*}{$\begin{array}{l}\text { Magnetic } \\
\text { moment } \mu_{\text {eff }} \\
\text { BM }\end{array}$} & \multirow{2}{*}{$\begin{array}{l}\text { Mol.Wt. } \\
\text { found } \\
\text { (Calcd) }\end{array}$} \\
\hline & & $\mathrm{C}$ & $\mathrm{H}$ & $\mathrm{N}$ & $\mathrm{M}$ & $\mathrm{Cl}$ & & & \\
\hline QBD & 78 & $\begin{array}{l}78.25 \\
(78.38)\end{array}$ & $\begin{array}{l}4.36 \\
(4.48)\end{array}$ & $\begin{array}{l}17.00 \\
(17.13)\end{array}$ & - & - & - & - & $\begin{array}{l}241.25 \\
(245.27)\end{array}$ \\
\hline QBO & 81 & $\begin{array}{l}78.01 \\
(78.06)\end{array}$ & $\begin{array}{l}4.23 \\
(4.06)\end{array}$ & $\begin{array}{l}11.32 \\
(11.38)\end{array}$ & - & - & - & $\begin{array}{l}240.32 \\
(246.26)\end{array}$ & \\
\hline$\left[\mathrm{Co}(\mathrm{QBD})_{2} \mathrm{Cl}_{2}\right]$ & 85 & $\begin{array}{l}62.14 \\
(62.17)\end{array}$ & $\begin{array}{l}3.18 \\
(3.23)\end{array}$ & $\begin{array}{l}13.44 \\
(13.58)\end{array}$ & $\begin{array}{l}9.16 \\
(9.53)\end{array}$ & $\begin{array}{l}11.38 \\
(11.46)\end{array}$ & 14.8 & 4.41 & $\begin{array}{l}624.56 \\
(620.39)\end{array}$ \\
\hline$\left[\mathrm{Ni}(\mathrm{QBD})_{2} \mathrm{Cl}_{2}\right]$ & 85 & $\begin{array}{l}62.24 \\
(62.09)\end{array}$ & $\begin{array}{l}3.14 \\
(3.23)\end{array}$ & $\begin{array}{l}13.39 \\
(13.57)\end{array}$ & $\begin{array}{l}9.36 \\
(9.48)\end{array}$ & $\begin{array}{l}11.25 \\
(11.45)\end{array}$ & 18.9 & 2.94 & $\begin{array}{l}625.12 \\
(620.15)\end{array}$ \\
\hline$\left[\mathrm{Cd}(\mathrm{QBD}) \mathrm{Cl}_{2}\right]$ & 81 & $\begin{array}{l}44.78 \\
(44.94)\end{array}$ & $\begin{array}{l}2.20 \\
(2.33)\end{array}$ & $\begin{array}{l}9.68 \\
(9.82)\end{array}$ & $\begin{array}{l}26.18 \\
(26.29)\end{array}$ & $\begin{array}{l}16.48 \\
(16.58)\end{array}$ & 13.31 & - & $\begin{array}{l}425.13 \\
(428.59)\end{array}$ \\
\hline$\left[\mathrm{Zn}(\mathrm{QBD}) \mathrm{Cl}_{2}\right]$ & 77 & $\begin{array}{l}50.72 \\
(50.50)\end{array}$ & $\begin{array}{l}2.58 \\
(2.62)\end{array}$ & $\begin{array}{l}11.10 \\
(11.03)\end{array}$ & $\begin{array}{l}17.08 \\
(17.18)\end{array}$ & $\begin{array}{l}18.58 \\
(18.63)\end{array}$ & 14.52 & - & $\begin{array}{l}378.46 \\
(381.54)\end{array}$ \\
\hline$\left[\mathrm{Co}(\mathrm{QBO})_{2} \mathrm{Cl}_{2}\right]$ & 85 & $\begin{array}{l}61.42 \\
(61.77)\end{array}$ & $\begin{array}{l}3.16 \\
(3.21)\end{array}$ & $\begin{array}{l}9.2 \\
(9.0)\end{array}$ & $\begin{array}{l}9.22 \\
(9.47)\end{array}$ & $\begin{array}{l}11.32 \\
(11.39)\end{array}$ & 25.2 & 4.83 & $\begin{array}{l}648.35 \\
(622.36)\end{array}$ \\
\hline$\left[\mathrm{Ni}(\mathrm{QBO})_{2} \mathrm{Cl}_{2}\right]$ & 83 & $\begin{array}{l}61.49 \\
(61.70)\end{array}$ & $\begin{array}{l}3.05 \\
(3.20)\end{array}$ & $\begin{array}{l}9.00 \\
(9.20)\end{array}$ & $\begin{array}{l}9.24 \\
(9.40)\end{array}$ & $\begin{array}{l}11.25 \\
(11.40)\end{array}$ & 25.7 & 3.01 & $\begin{array}{l}618.25 \\
(622.12)\end{array}$ \\
\hline$\left[\mathrm{Cd}(\mathrm{QBO}) \mathrm{Cl}_{2}\right]$ & 80 & $\begin{array}{l}44.59 \\
(44.73)\end{array}$ & $\begin{array}{l}2.34 \\
(2.35)\end{array}$ & $\begin{array}{l}6.42 \\
(6.52)\end{array}$ & $\begin{array}{l}26.08 \\
(26.17)\end{array}$ & $\begin{array}{l}16.41 \\
(16.51)\end{array}$ & 15.84 & - & $\begin{array}{l}426.61 \\
(429.58)\end{array}$ \\
\hline$\left[\mathrm{Zn}(\mathrm{QBO}) \mathrm{Cl}_{2}\right]$ & 73 & $\begin{array}{l}50.26 \\
(50.23)\end{array}$ & $\begin{array}{l}2.51 \\
(2.63)\end{array}$ & $\begin{array}{l}7.25 \\
(7.32)\end{array}$ & $\begin{array}{l}17.06 \\
(17.09)\end{array}$ & $\begin{array}{l}18.35 \\
(18.53)\end{array}$ & 16.75 & - & $\begin{array}{l}378.76 \\
(382.6)\end{array}$ \\
\hline
\end{tabular}

\subsection{Electronic and reflectance spectra}

The Co(II) complexes exhibit three bands in the visible region $13310-14250 \mathrm{~cm}^{-1}, 14810-14988 \mathrm{~cm}^{-1}$, and $16425-$ $16431 \mathrm{~cm}^{-1}$ pertaining to ${ }^{4} \mathrm{~T}_{1 \mathrm{~g}}(\mathrm{~F}) \rightarrow{ }^{4} \mathrm{~T}_{2 \mathrm{~g}}(\mathrm{~F})\left(\nu_{1}\right),{ }^{4} \mathrm{~T}_{1 \mathrm{~g}}(\mathrm{~F})$ $\rightarrow{ }^{4} \mathrm{~A}_{2 \mathrm{~g}}(\mathrm{~F})\left(\nu_{2}\right)$, and ${ }^{4} \mathrm{~T}_{1 \mathrm{~g}}(\mathrm{~F}) \rightarrow{ }^{4} \mathrm{~T}_{1 \mathrm{~g}}(\mathrm{P})\left(\nu_{3}\right)$ transitions, respectively. These electronic spectral data were consistent with high-spin octahedral configuration around $\mathrm{Co}$ (II) ion $[11,12]$. The electronic spectra of $\mathrm{Ni}(\mathrm{II})$ complexes of QBD and QBO show two bands in the region 12610$16260 \mathrm{~cm}^{-1}$ and $23256-28011 \mathrm{~cm}^{-1}$ due to ${ }^{3} \mathrm{~A}_{2 \mathrm{~g}(\mathrm{~F})} \rightarrow{ }^{3} \mathrm{~T}_{1 \mathrm{~g}(\mathrm{~F})}$ $\left(\nu_{2}\right)$ and ${ }^{3} \mathrm{~A}_{2 \mathrm{~g}(\mathrm{~F})} \rightarrow{ }^{3} \mathrm{~T}_{\lg (\mathrm{P})}\left(\nu_{3}\right)$ transitions, respectively, that commensurate with octahedral stereochemistry [13]. The reflectance spectra is identical for both $\mathrm{Zn}$ (II) and $\mathrm{Cd}(\mathrm{II})$ complexes. The spectra of the complexes do not indicate lowest energy ${ }^{3} \mathrm{~A}_{2 \mathrm{~g}} \rightarrow{ }^{3} \mathrm{~T}_{2 \mathrm{~g}}$ transition. The $\mathrm{Zn}(\mathrm{II})$ complex shows two week low energy bands at $\sim 15155 \mathrm{~cm}^{-1}$ and $\sim 19500 \mathrm{~cm}^{-1}$. This is due to metal ligand charge transfer process ascribed to a charge transfer from $d$ orbital of the metal to the $\pi^{*}$ system of the ligand [14-16]. The lowenergy bands are in the position typically found for square planer configuration and may be assigned to ${ }^{2} \mathrm{~B}_{1 \mathrm{~g}} \rightarrow{ }^{2} \mathrm{~A}_{1 \mathrm{~g}}$ and ${ }^{2} \mathrm{~B}_{1 \mathrm{~g}} \rightarrow{ }^{2} \mathrm{E}_{\mathrm{g}}$ transition, respectively. These complexes also exhibit more intense band at $37000 \mathrm{~cm}^{-1}$ which corresponds to intra ligand molecular charge transfer within the ligand that are assigned to $\mathrm{n} \rightarrow \pi^{*}$ transitions. The absence of $\mathrm{d}-\mathrm{d}$ bands in these complexes at longer wavelength is quite rea- sonable since the metal ion has filled d-sub shells where d$\mathrm{d}$ transitions are highly forbidden [17, 18]. By considering these data, the tetrahedral geometry has been proposed for $\mathrm{Cd}(\mathrm{II})$ [19] and square planar geometry for $\mathrm{Zn}$ (II) complexes $[20,21]$.

\subsection{Magnetic moments}

The room temperature magnetic moment value (Table 1) supports octahedral geometry for $\mathrm{Co}$ (II) and $\mathrm{Ni}$ (II) complexes. The complexes $\mathrm{Zn}$ (II) and $\mathrm{Cd}$ (II) are diamagnetic due to the unavailability of unpaired electrons [11-13, 19-21].

\subsection{IR spectra}

The IR spectra of complexes are compared with that of free ligands to determine the changes that might have taken place during complexation. The important bands and assignments of ligands and their complexes are summarized in Table 2. The results indicate that the ligands are bidentate [22-28] in nature.

The free ligand QBD exhibits strong bands at 1658 and $3330 \mathrm{~cm}^{-1}$ due to $\mathrm{C}=\mathrm{N}$ and $-\mathrm{NH}$ groups, respectively. In the IR spectra of complexes, these bands shift $\left(10-35 \mathrm{~cm}^{-1}\right)$ towards the lower energies when compared with free ligands. The characteristic absorptions at 1650 and $1022 \mathrm{~cm}^{-1}$ in $\mathrm{QBO}$ were assigned to the stretching vibrations of $\nu(\mathrm{C}=\mathrm{N})$ 
TABLE 2: IR and ${ }^{1} \mathrm{H}$ NMR spectral data.

\begin{tabular}{|c|c|c|c|c|c|c|}
\hline \multirow{2}{*}{ Compound } & \multicolumn{5}{|c|}{ Infrared spectral data } & \multirow{2}{*}{${ }^{1} \mathrm{H}$ NMR spectral data $(\delta, \mathrm{ppm})$} \\
\hline & $\nu(\mathrm{C}=\mathrm{N})$ & $\nu(\mathrm{NH})$ & $v(\mathrm{COC})$ & $v \mathrm{M}-\mathrm{N}$ & $v \mathrm{M}-\mathrm{X}$ & \\
\hline QBD & 1658 & 3330 & - & - & - & $\begin{array}{c}10.65(\mathrm{~s}, 1 \mathrm{H}, \mathrm{NH}), 7.2-7.8(\mathrm{~m}, 9 \mathrm{H}, \mathrm{Ar}-\mathrm{H}) \\
8.4(\mathrm{~s}, 1 \mathrm{H}, \mathrm{H}-\mathrm{C}=\mathrm{N})\end{array}$ \\
\hline QBO & 1651 & - & 1022 & - & - & $\begin{array}{c}8.3(\mathrm{~s}, 1 \mathrm{H}, \mathrm{H}-\mathrm{C}=\mathrm{N}) \\
7.1-8.0(\mathrm{~m}, 9 \mathrm{H}, \mathrm{Ar}-\mathrm{H})\end{array}$ \\
\hline$\left[\mathrm{Co}(\mathrm{QBD})_{2} \mathrm{Cl}_{2}\right]$ & 1615 & 3320 & - & 440 & 350 & $\begin{array}{c}10.95(\mathrm{~s}, 1 \mathrm{H}, \mathrm{NH}), 7.2-8.8(\mathrm{~m}, 9 \mathrm{H}, \mathrm{Ar}-\mathrm{H}) \\
8.4(\mathrm{~s}, 1 \mathrm{H}, \mathrm{H}-\mathrm{C}=\mathrm{N})\end{array}$ \\
\hline$\left[\mathrm{Co}(\mathrm{QBO})_{2} \mathrm{Cl}_{2}\right]$ & 1615 & - & 995 & 458 & 368 & $\begin{array}{c}8.3(\mathrm{~s}, 1 \mathrm{H}, \mathrm{H}-\mathrm{C}=\mathrm{N}) \\
7.5-8.9(\mathrm{~m}, 9 \mathrm{H}, \mathrm{Ar}-\mathrm{H})\end{array}$ \\
\hline$\left[\mathrm{Ni}(\mathrm{QBD})_{2} \mathrm{Cl}_{2}\right]$ & 1620 & 3310 & - & 467 & 250 & $\begin{array}{c}10.90(\mathrm{~s}, 1 \mathrm{H}, \mathrm{NH}), 7.2-8.8(\mathrm{~m}, 9 \mathrm{H}, \mathrm{Ar}-\mathrm{H}) \\
8.4(\mathrm{~s}, 1 \mathrm{H}, \mathrm{H}-\mathrm{C}=\mathrm{N})\end{array}$ \\
\hline$\left[\mathrm{Ni}(\mathrm{QBO})_{2} \mathrm{Cl}_{2}\right]$ & 1631 & - & 996 & 449 & 264 & $\begin{array}{c}8.3(\mathrm{~s}, 1 \mathrm{H}, \mathrm{H}-\mathrm{C}=\mathrm{N}) \\
7.5-8.9(\mathrm{~m}, 9 \mathrm{H}, \mathrm{Ar}-\mathrm{H})\end{array}$ \\
\hline$\left[\mathrm{Zn}(\mathrm{QBD}) \mathrm{Cl}_{2}\right]$ & 1625 & 2990 & - & 428 & 348 & $\begin{array}{c}10.90(\mathrm{~s}, 1 \mathrm{H}, \mathrm{NH}), 7.2-7.8(\mathrm{~m}, 9 \mathrm{H}, \mathrm{Ar}-\mathrm{H}) \\
8.4(\mathrm{~s}, 1 \mathrm{H}, \mathrm{H}-\mathrm{C}=\mathrm{N})\end{array}$ \\
\hline$\left[\mathrm{Zn}(\mathrm{QBO}) \mathrm{Cl}_{2}\right]$ & 1615 & - & 1002 & 432 & 350 & $\begin{array}{c}8.3(\mathrm{~s}, 1 \mathrm{H}, \mathrm{H}-\mathrm{C}=\mathrm{N}) \\
7.5-8.9(\mathrm{~m}, 9 \mathrm{H}, \mathrm{Ar}-\mathrm{H})\end{array}$ \\
\hline$\left[\mathrm{Cd}(\mathrm{QBD}) \mathrm{Cl}_{2}\right]$ & 1610 & 3300 & - & 432 & 348 & $\begin{array}{c}10.85(\mathrm{~s}, 1 \mathrm{H}, \mathrm{NH}), 7.2-7.8(\mathrm{~m}, 9 \mathrm{H}, \mathrm{Ar}-\mathrm{H}) \\
8.4(\mathrm{~s}, 1 \mathrm{H}, \mathrm{H}-\mathrm{C}=\mathrm{N})\end{array}$ \\
\hline $\left.\mathrm{Cd}(\mathrm{QBO}) \mathrm{Cl}_{2}\right]$ & 1610 & - & 998 & 428 & 360 & $\begin{array}{c}8.3(\mathrm{~s}, 1 \mathrm{H}, \mathrm{H}-\mathrm{C}=\mathrm{N}) \\
7.1-8.0(\mathrm{~m}, 9 \mathrm{H}, \mathrm{Ar}-\mathrm{H})\end{array}$ \\
\hline
\end{tabular}

and $v(\mathrm{COC})$ groups, respectively. In the complexes, these vibrations shift to lower regions by $10-25 \mathrm{~cm}^{-1}$. The shift of these bands in complexes suggests the coordination of nitrogen of quinoline ring and oxygen atom of azepine ring of ligand to metal ions. The bonding of metal ion to the ligands through $\mathrm{N}, \mathrm{N}$ in $\mathrm{QBD}$ and $\mathrm{N}, \mathrm{O}$ atoms in QBO was further supported by the presence of new bands in the region 328$375 \mathrm{~cm}^{-1}$ due to $v(\mathrm{M}-\mathrm{N})$ and $\nu(\mathrm{M}-\mathrm{O})$ vibrations [29-31].

\section{4. ${ }^{1}$ H NMR spectra}

The above binding pattern is further supported by proton magnetic resonance spectral studies and chemical shift values presented in Table 2 . The ${ }^{1} \mathrm{H}$ NMR spectra of ligand QBD exhibits a singlet at $10.80 \delta(\mathrm{s}, \mathrm{N}-\mathrm{H})$ and $8.6 \delta(\mathrm{s}$, $\mathrm{H}-\mathrm{C}=\mathrm{N}$ ). The spectra of complexes slightly changed as compared to those of corresponding ligand, and the signals appeared downfield, as expected, due to the coordination of nitrogen atoms to the metal ion [32-37]. ${ }^{1} \mathrm{H}$ NMR spectrum of QBO ligand showed signals at $\delta 8.4(\mathrm{~s}, 1 \mathrm{H}, \mathrm{H}-\mathrm{C}=\mathrm{N}), 7.3-$ $8.0(\mathrm{~m}, 11 \mathrm{H}, \mathrm{Ar}-\mathrm{H})$, and $2.6\left(\mathrm{~s}, 3 \mathrm{H}, \mathrm{CH}_{3}\right)$. In the spectra of complexes, all signals remained in the same position except the signal of $\mathrm{H}-\mathrm{C}=\mathrm{N}$. This is probably due to the coordinating effect of azepine oxygen atom.

\section{BIOLOGICAL STUDIES}

\subsection{Antibacterial activity}

The ligands and their $\mathrm{Co}(\mathrm{II}), \mathrm{Ni}(\mathrm{II}), \mathrm{Cd}(\mathrm{II})$ and $\mathrm{Zn}$ (II) complexes were tested for the in vitro antibacterial activity against $P$. aerugenosa (gram-negative) and S. aureus (gram-positive) bacteria by employing paper disc method [38-41]. The antibacterial activity was estimated on the basis of the size of inhibition zone formed around the paper discs on the seeded agar plates. For each concentration, the mean diameter ( $\mathrm{mm})$ of inhibition zone developed was calculated. The streptomycin (100 mg) was used as a standard and DMF solvent was also put to know the activity of solvent.

\subsection{Antifungal activity}

The antifungal studies of ligands and its metal complexes were tested on fungal strains namely, C. albicans, A. flavus, and $A$. niger in growth media by using Batemann poisonedfood technique $[42,43]$. A known weight of the compound was dissolved in DMF in suitably labeled sterile test tubes to get a final concentration of $0.1,0.2$, and $0.3 \%$. The sterile medium, sterile ligand, and metal complex solution were mixed under sterile conditions and allowed for solidification. The Fluconazole (100 mg) was used as a standard and DMF solvent was also put to know the activity of solvent.

The test fungi were taken as $2 \mathrm{~mm}$ discs from 10 days old pure colonies and placed at the center of petri dishes containing nutrient medium. The experiment was carried out in four replicates per treatment, and incubation was carried out at $30^{\circ} \mathrm{C}$ for 72 hours. The radial growth of colony was recorded after 96 hours of incubation and mean diameter of mycelial growth in each treatment was recorded. The average percentage inhibition was calculated on the growth media compared to the respective controls using expression [44] $\mathrm{I}=(\mathrm{C}-\mathrm{T}) \times 100 / \mathrm{C}$, where $\mathrm{I}=$ percentage inhibition, $\mathrm{C}=\mathrm{av}-$ erage diameter of fungal growth on the control plates, and 
TABle 3: Antimicrobial activities.

\begin{tabular}{|c|c|c|c|c|c|c|c|c|c|c|c|c|c|c|c|}
\hline \multirow{3}{*}{ Compound } & \multicolumn{6}{|c|}{ Inhibition zone of bacterial growth (mm) } & \multicolumn{9}{|c|}{ Percentage inhibition of fungicidal growth } \\
\hline & \multicolumn{3}{|c|}{$P$. aerugenosa } & \multicolumn{3}{|c|}{ S. aureus } & \multicolumn{3}{|c|}{ C. albicans } & \multicolumn{3}{|c|}{ A. niger } & \multicolumn{3}{|c|}{ A. flavus } \\
\hline & $0.1 \%$ & $0.2 \%$ & $0.3 \%$ & $0.1 \%$ & $0.2 \%$ & $0.3 \%$ & $0.1 \%$ & $0.2 \%$ & $0.3 \%$ & $0.1 \%$ & $0.2 \%$ & $0.3 \%$ & $0.1 \%$ & $0.2 \%$ & $0.3 \%$ \\
\hline QBD & 1.2 & 1.6 & 2.8 & 1.4 & 1.8 & 3.0 & 11.2 & 13.8 & 18.3 & 10.3 & 13.4 & 20.2 & 9.8 & 13.1 & 24.2 \\
\hline QBO & 1.1 & 2.0 & 3.0 & 1.3 & 1.6 & 2.9 & 10.3 & 12.9 & 16.9 & 8.8 & 11.9 & 18.6 & 7.8 & 11.8 & 22.3 \\
\hline$\left[\mathrm{Zn}(\mathrm{QBD}) \mathrm{Cl}_{2}\right]$ & 2.2 & 2.7 & 4.3 & 2.3 & 3.1 & 5.1 & 13.2 & 20.5 & 29.6 & 13.2 & 16.9 & 23.2 & 12.4 & 15.2 & 27.5 \\
\hline$\left[\mathrm{Cd}(\mathrm{QBD}) \mathrm{Cl}_{2}\right]$ & 1.8 & 2.4 & 3.9 & 2.0 & 2.8 & 4.3 & 12.9 & 18.5 & 25.6 & 12.1 & 16.0 & 22.4 & 11.3 & 14.3 & 26.3 \\
\hline$\left[\mathrm{Co}(\mathrm{QBD})_{2} \mathrm{Cl}_{2}\right]$ & 1.6 & 2.0 & 3.4 & 1.7 & 2.3 & 3.6 & 12.7 & 15.9 & 23.0 & 11.3 & 14.5 & 21.5 & 10.6 & 13.6 & 25.2 \\
\hline$\left[\mathrm{Ni}(\mathrm{QBD})_{2} \mathrm{Cl}_{2}\right]$ & 1.5 & 2.0 & 3.2 & 1.7 & 2.2 & 3.5 & 11.6 & 15.2 & 22.1 & 11.0 & 14.3 & 21.3 & 10.5 & 13.5 & 25.1 \\
\hline$\left[\mathrm{Zn}(\mathrm{QBO}) \mathrm{Cl}_{2}\right]$ & 1.8 & 3.2 & 4.2 & 2.1 & 2.9 & 4.3 & 12.3 & 19.8 & 28.5 & 11.5 & 14.9 & 21.1 & 10.2 & 14.4 & 25.3 \\
\hline$\left[\mathrm{Cd}(\mathrm{QBO}) \mathrm{Cl}_{2}\right]$ & 1.6 & 2.9 & 3.7 & 2.0 & 2.6 & 3.9 & 11.8 & 17.8 & 25.2 & 10.5 & 14.1 & 20.1 & 9.1 & 13.5 & 24.6 \\
\hline$\left[\mathrm{Co}(\mathrm{QBO})_{2} \mathrm{Cl}_{2}\right]$ & 1.5 & 2.6 & 3.5 & 1.6 & 2.2 & 3.4 & 11.1 & 15.6 & 22.0 & 9.8 & 13.0 & 19.3 & 8.6 & 12.9 & 23.4 \\
\hline$\left[\mathrm{Ni}(\mathrm{QBO})_{2} \mathrm{Cl}_{2}\right]$ & 1.5 & 2.5 & 3.5 & 1.6 & 2.1 & 3.3 & 11.1 & 14.9 & 21.5 & 9.7 & 12.9 & 19.2 & 8.5 & 12.8 & 23.2 \\
\hline Streptomycin & 4.0 & 12.0 & 13.5 & 9.4 & 14.5 & 26.7 & - & - & - & - & - & - & - & - & - \\
\hline Fluconazole & - & - & - & - & - & - & 36.2 & 55.5 & 70.0 & 36.0 & 40.0 & 65.8 & 37.5 & 48.9 & 75.4 \\
\hline DMF & +ve & +ve & +ve & $+\mathrm{ve}$ & $+\mathrm{ve}$ & $+\mathrm{ve}$ & $+\mathrm{ve}$ & +ve & +ve & + ve & $+\mathrm{ve}$ & +ve & $+\mathrm{ve}$ & $+\mathrm{ve}$ & $+\mathrm{ve}$ \\
\hline
\end{tabular}

DMF is used as control, +ve indicates growth of microbes.

$\mathrm{T}=$ average diameter of fungal growth on the tested plates (Table 3).

Antibacterial and antifungal data are presented in Table 3. This screening data clearly leads to the following conclusion.

(i) The complexes are slightly more toxic than their parent ligands against tested microorganisms under identical experimental conditions.

(ii) The antimicrobial activity results indicate that the activity of $\mathrm{Zn}$ (II) complexes show better activity than that of $\mathrm{Cd}(\mathrm{II}), \mathrm{Co}(\mathrm{II})$, and $\mathrm{Ni}$ (II) complexes.

(iii) The antifungal screening data clearly shows that the inhibition of fungal growth increases with increasing the concentration of complexes.

\section{ACKNOWLEDGMENTS}

The authors thank the Head of the Department of Industrial Chemistry, Kuvempu University, Shimoga, for providing laboratory facilities. One of the authors (B. Basavaraju) wishes to acknowledge financial support from Mr. G. M. Lingaraju, Secretary, GM Institute of Technology, Davangere 577 006, Karnataka, India.

\section{REFERENCES}

[1] G. Bringmann, Y. Reichert, and V. Kane, "The total synthesis of streptonigrin and related antitumor antibiotic natural products," Tetrahedron, vol. 60, no. 16, pp. 3539-3574, 2004.

[2] E. Chiari, A. B. Oliveira, M. A. Prado, R. J. Alves, L. M. Galvão, and F. G. Araujo, "Potential use of WR6026 as prophylaxis against transfusion-transmitted American trypanosomiasis," Antimicrobial Agents and Chemotherapy, vol. 40, no. 3, pp. 613-615, 1996.

[3] N. P. Sahu, C. Pal, N. B. Mandal, et al., "Synthesis of a novel quinoline derivative, 2-(2-methylquinolin4-ylamino)- $N$-phenylacetamide-a potential antileishmanial agent," Bioorganic \& Medicinal Chemistry, vol. 10, no. 6, pp. 1687-1693, 2002.

[4] Chiang Su New Medical College, Dictionary of Chinese Crude Drugs, Shanghai Scientific Technological, Shanghai, China, 1997.

[5] K. Kim, H. Kim, K. Park, and K. Cho, "Structural characterization of a new antibiotic substance purified from Scolopendra subspinipes multilans L. Koch," Journal of the Korean Chemical Society, vol. 42, no. 2, pp. 236-239, 1998.

[6] T. H. M. Jonckers, S. van Miert, K. Cimanga, et al., "Synthesis, cytotoxicity, and antiplasmodial and antitrypanosomal activity of new neocryptolepine derivatives," Journal of Medicinal Chemistry, vol. 45, no. 16, pp. 3497-3508, 2002.

[7] L. Dassonneville, A. Lansiaux, A. Wattelet, et al., "Cytotoxicity and cell cycle effects of the plant alkaloids cryptolepine and neocryptolepine : relation to drug-induced apoptosis," European Journal of Pharmacology, vol. 409, no. 1, pp. 9-18, 2000.

[8] J. Godlewska, K. Badowska-Roslonek, J. Ramza, L. Kaczmarek, W. Peczynska-Czoch, and A. Opolski, "New saccharide derivatives of indolo[2,3-b]quinoline as cytotoxic compounds and topoisomerase II inhibitors," Radiology and Oncology, vol. 38, no. 2, pp. 137-144, 2004.

[9] P. M. O’Neill, P. G. Bray, S. R. Hawley, S. A. Ward, and B. K. Park, "4-aminoquinolines-past, present, and future: a chemical perspective,” Pharmacology \& Therapeutics, vol. 77, no. 1, pp. 29-58, 1998.

[10] M. Foley and L. Tilley, "Quinoline antimalarials: mechanisms of action and resistance and prospects for new agents," Pharmacology \& Therapeutics, vol. 79, no. 1, pp. 55-87, 1998.

[11] A. B. P. Lever, Inorganic Electron Spectroscopy, Elsevier, Amsterdam, The Netherlands, 1968.

[12] J. E. Huheey, Inorganic Chemistry: Principles of Structure and Reactivity, Harper and Row, NewYork, NY, USA, 1980.

[13] R. S. Drago, Physical Methods in Inorganic Chemistry, Rein Hold, New York, NY, USA, 1965.

[14] B. N. Figgis, Introduction to Ligand Field Theory, Wiley Eastern, New Delhi, India, 2nd edition, 1976.

[15] S. Arounaguiri, D. Easwaramoorthy, A. Ashokkumar, A. Dattagupta, and B. M. Maiya, "Cobalt(III), nickel(II) and ruthenium(II) complexes of 1,10-phenanthroline family of 
ligands: DNA binding and photocleavage studies," Proceeding of Indian Academy of Sciences: Chemical Science, vol. 112, no. 1, pp. 1-17, 2000.

[16] J. Kamenček, P. Solichová, and Z. Šindelár, "Ni(II) and Co(II) complexes with aliphatic 1,2-ethanedithiol and selected N,Pligands," Acta Univiersitatis Palackiane Olomucensis Facultas Rerum Naturalium, vol. 40, pp. 35-40, 2001.

[17] A. Kriza, A. Reiss, S. Blejoiu, L. Brujan, and N. Stanica, "Transition metal complexes of heterocyclic ligands-part II: complex compounds of ions with $d^{6}, d^{7}, d^{8}$ and $d^{10}$ electronic configuration with 3-N-dibenzofurylthiourea," Journal of the Indian Chemical Society, vol. 77, no. 10, pp. 488-489, 2000.

[18] Q.-L. Zhang, J.-H. Liu, X.-Z. Ren, et al., "A functionalized cobalt(III) mixed-polypyridyl complex as a newly designed DNA molecular light switch," Journal of Inorganic Biochemistry, vol. 95, no. 2-3, pp. 194-198, 2003.

[19] C. V. Sastri, D. Eswaramoorthy, L. Giribabu, and B. G. Maiya, "DNA interactions of new mixed-ligand complexes of cobalt(III) and nickel(II) that incorporate modified phenanthroline ligands," Journal of Inorganic Biochemistry, vol. 94, no. 1-2, pp. 138-145, 2003.

[20] R. N. Prasad and M. Mathur, "Synthesis characterization of $\mathrm{Cr}(\mathrm{III}), \mathrm{Fe}(\mathrm{III}), \mathrm{Co}(\mathrm{II}), \mathrm{Ni}(\mathrm{II}), \mathrm{Cu}(\mathrm{II})$ and $\mathrm{Zn}(\mathrm{II})$ complexes of 2,12-dimethyl-3-13-di-n-propyl-1,4,11,14-tetraazacycloeicosa-1,13,11,13-tetraene," Journal of the Serbian Chemical Society, vol. 67, no. 12, pp. 825-832, 2002.

[21] B. Ramachandra and B. Narayana, "Complexing behaviour of 4-vanillideneamino-3-methyl-5-mercapto-1,2,4-triazole towards $\mathrm{Ag}^{\mathrm{I}}, \mathrm{Ti}^{\mathrm{I}}, \mathrm{Zn}^{\mathrm{II}}, \mathrm{Pb}^{\mathrm{II}}, \mathrm{Cd}^{\mathrm{II}}, \mathrm{Hg}^{\mathrm{II}}, \mathrm{Co}^{\mathrm{II}}, \mathrm{Ni}^{\mathrm{iI}}, \mathrm{Pd}^{\mathrm{II}}, \mathrm{Rh}^{\mathrm{III}}$, and Ir ${ }^{\mathrm{III}}$," Journal of the Indian Chemical Society, vol. 77, pp. 440-441, 2000.

[22] B. Kalluraya, R. Gururaja, and G. Rai, "One pot reaction: synthesis, characterization and biological activity of 3-alkyl/aryl9-substituted-1,2,4-triazolo [3,4-b][1,3,4] quinolino thiadiazepines," Indian Journal of Chemistry, vol. 42B, no. 1, pp. 211214, 2003.

[23] K. Mogilaiah and G. Rama Sudhakar, "Synthesis of pyrazoline, pyrimidine and 1,5-benzodiazepine derivatives of 1,8naphthyridine and evaluation of antibacterial activity," Indian Journal of Chemistry, vol. 42B, no. 3, pp. 636-640, 2003.

[24] R. Nandha Kumar, S. Thamarai Selvi, T. Suresh, and P. S. Mohan, "Reactions of heterocyclic quinone methides: a facile entry to synthesize the alkaloid, flindersine and its analogues," Indian Journal of Chemistry, vol. 42B, no. 1, pp. 187-188, 2003.

[25] W. T. Gao and Z. Zheng, "Synthetic studies on optically active Schiff-base ligands derived from condensation of 2hydroxyacetophenone and chiral diamines," Molecules, vol. 7, pp. 511-516, 2002.

[26] S. Grevea, V. Vill, and W. Friedrichsena, "Novel nitronyl nitroxides: synthesis and properties," Zeitschrift für Naturforschung, vol. 57B, pp. 677-684, 2002.

[27] G. L. Plourde and B. B. Fisher, "Synthesis of 6-methoxy1-oxaspiro[4,5]deca-6,9-diene-8-one," Molecules, vol. 7, pp. 315-319, 2002.

[28] D. G. Rivera, K. Peseke, I. Jomarrón, A. Montero, R. Molina, and F. Coll, "Synthesis of new pyrazole and pyrimidine steroidal derivatives,” Molecules, vol. 8, pp. 444-452, 2003.

[29] S. I. Black and G. B. Young, "Synthesis and spectroscopic characteristics of 2-methyl-2-phenylpropyl- and dimethyl(phenyl)silylmethylnickel(II) complexes," Polyhedron, vol. 8, no. 5, pp. 585-596, 1989.

[30] C. C. Addison and N. Logan, Advances in Inorganic Chemistry and Radiochemistry, Academic Press, New York, NY, USA, 1964.
[31] H. S. Bhojya Naik, P. R. Chetana, and H. D. Revanasiddappa, "Complexes of divalent cadmium with N,N-dimethyl-3-dibenzo[b,e]-oxepin-11-(6H)-ylidine-1-propanamine)chloride: synthesis and evaluation of thermal degradation kinetics," Journal of the Indian Chemical Society, vol. 79, no. 12, pp. 955-957, 2002.

[32] A. Gupta, R. Sirohi, S. Shastri, and D. Kishore, "A versatile approach for the synthesis of 1-methyl-4H[1,2,4] triazolo[4,3a] $[1,4]$ benzodiazepine $\mathrm{N}^{5}$-oxide," Journal of the Indian Chemical Society, vol. 81, no. 2, pp. 163-166, 2004.

[33] M. M. Ismail, M. Abass, and M. M. Hassan, "Chemistry of substituted quinolinones-part VI: synthesis and nucleophilic reactions of 4-chloro-8-methylquinolin-2(1H)-one and its thione analogue," Molecules, vol. 5, pp. 1224-1239, 2000.

[34] B. Keshavan and R. T. Radhika, "Synthesis and structural investigation of biologically active complexes of lanthanide with chlorpromazine," Indian Journal of Chemistry, vol. 39A, no. 4, pp. 425-429, 2000.

[35] A. Kiss-Szikszai, T. Patonay, and J. Jeko, "Synthesis of 2-(substituted-phenyl)-5-(aminomethyl)- and (thiomethyl)1,3,4-oxadiazoles. Oxidation of thiomethyl-oxadiazole derivatives by dimethyldioxirane," Arkivoc, vol. 2001, part 3, pp. 4050.

[36] K. Mogilaiah, M. Prashanthi, and K. Vidya, "Efficient synthesis of 1,2,4-triazolo[4,3-a][1,8]naphthyridines using nitrous acid under microwave irradiation," Indian Journal of Chemistry, vol. 43B, no. 12, pp. 2641-2645, 2004.

[37] D. Ramesh and B. Sreenivasulu, "Synthesis of 2-methyl-3(5' -aryl'aryloxymethyl-1', 3', 4' -oxadiazol-2' -yl) amino-1,8naphthyridines as possible antimicrobial agents," Indian Journal of Heterocyclic Chemistry, vol. 13, no. 2, pp. 163-164, 2003.

[38] P. C. Fahy and G. J. Persley, Plant Bacterial Diseases, Diagnostic Guide, Academic Press, New York, NY, USA, 1983.

[39] P. G. Ramappa and K. G. Somasekharappa, "Structure and antimicrobial activity of some new diphenylpyraline complexes of iron(III) chloride, nitrate, sulphate, and thiocyanate," Journal of Inorganic Biochemistry, vol. 55, no. 1, pp. 13-20, 1994.

[40] H. S. Bhojya Naik and P. G. Ramappa, "Isolation, characterization and antimicrobial activity of imipramine-cobalt (II) complexes," Asian Journal of Chemistry, vol. 8, no. 4, pp. 644-648, 1996.

[41] R. S. Srivastava, "Pseudotetrahedral Co(II), Ni(II) and $\mathrm{Cu}$ (II) complexes of $\mathrm{N}^{1}$-(O-chlorophenyl)-2-(2',4'-dihydroxyphenyl)-2-benzylazomethine their fungicidal and herbicidal activity," Inorganica Chimica Acta, vol. 56, pp. L65-L67, 1981.

[42] D. Monger and R. K. Groover, "Chemical control root of cow pea in relation to altered pathogenicity of F. Solani," Indian Phytopathology, vol. 44, no. 4, pp. 462-469, 1991.

[43] H. Suberu, "Preliminary studies of inhibitions in Aspergillus flavus with extracts of two lichens and Bentex-T fungicide," African Journal of Biotechnology, vol. 3, no. 9, pp. 468-472, 2004.

[44] C. Kaiser, R. van der Merwe, T. F. Bekker, and N. Labuschagne, "In-vitro inhibition of mycelial growth of several phytopathogenic fungi, including Phytophthora cinnamomi by soluble silicon," South African Avocado Growers' Association Yearbook, vol. 28, pp. 70-74, 2005. 


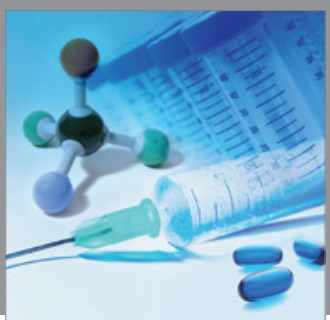

International Journal of

Medicinal Chemistry

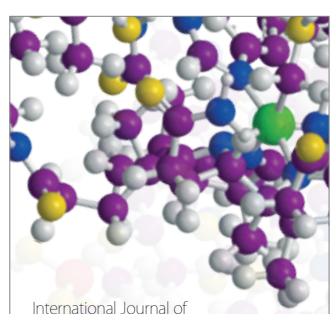

Carbohydrate Chemistry

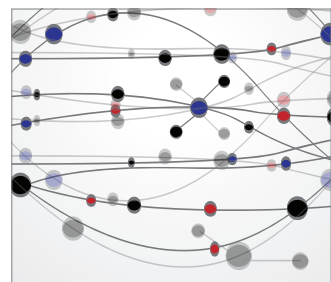

The Scientific World Journal
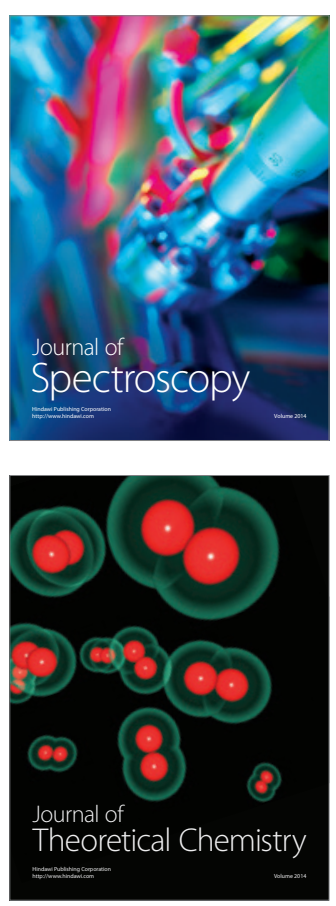
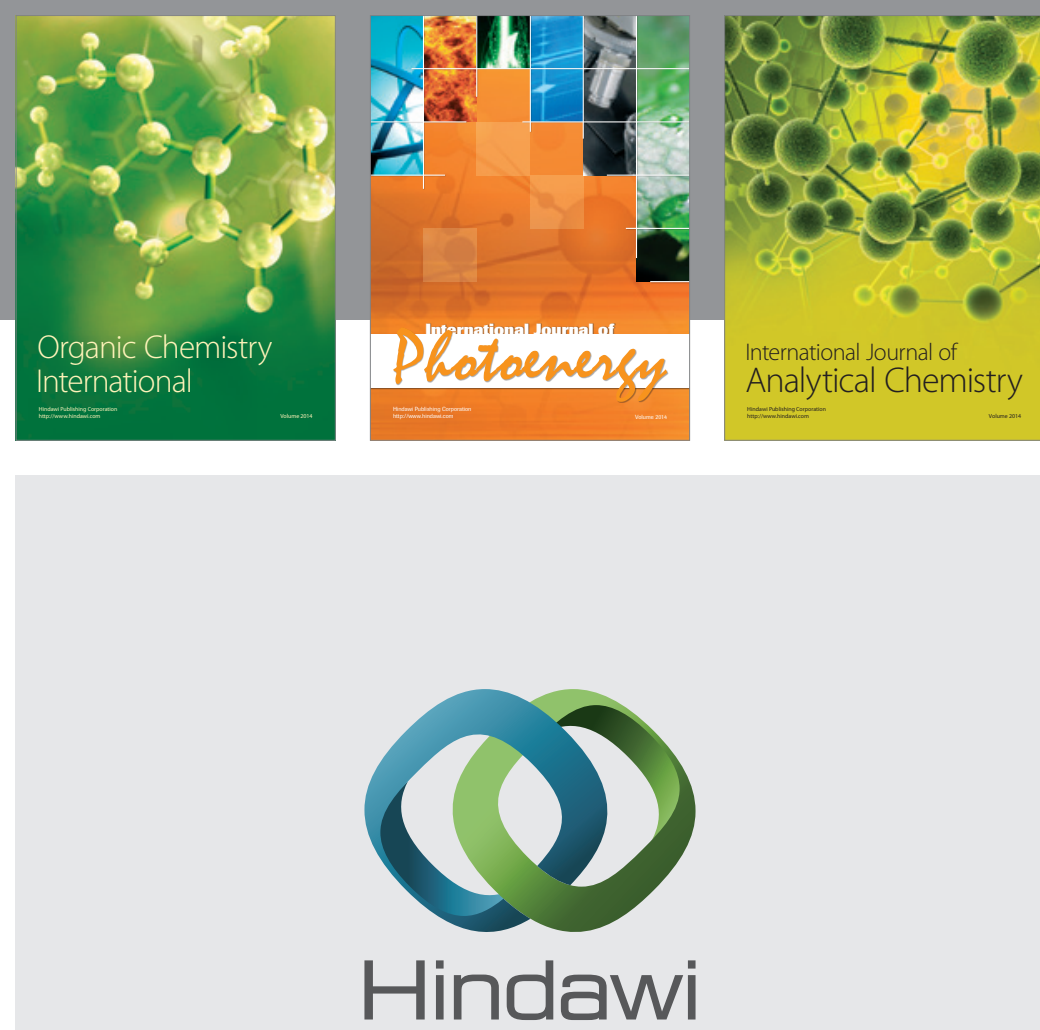

Submit your manuscripts at

http://www.hindawi.com
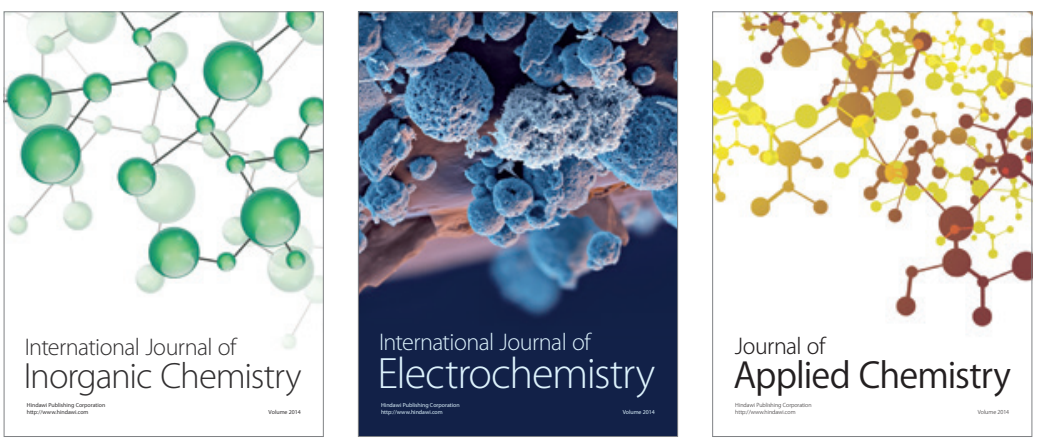

Journal of

Applied Chemistry
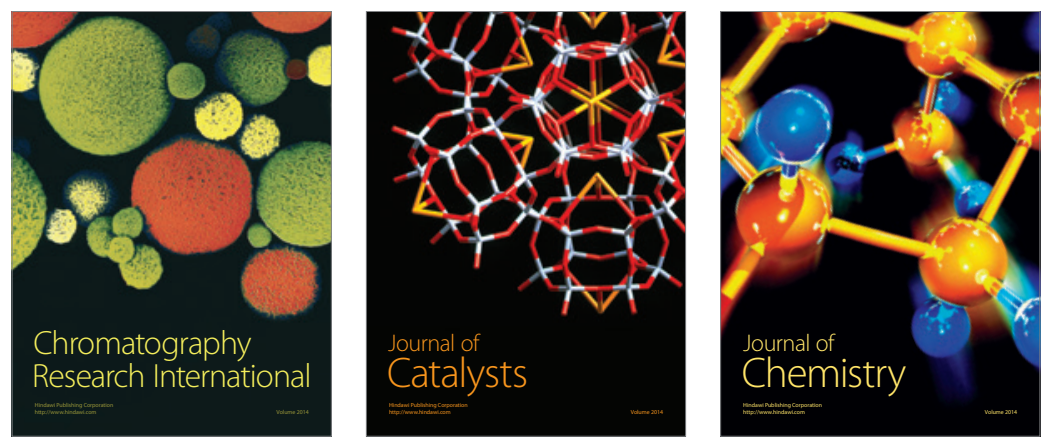
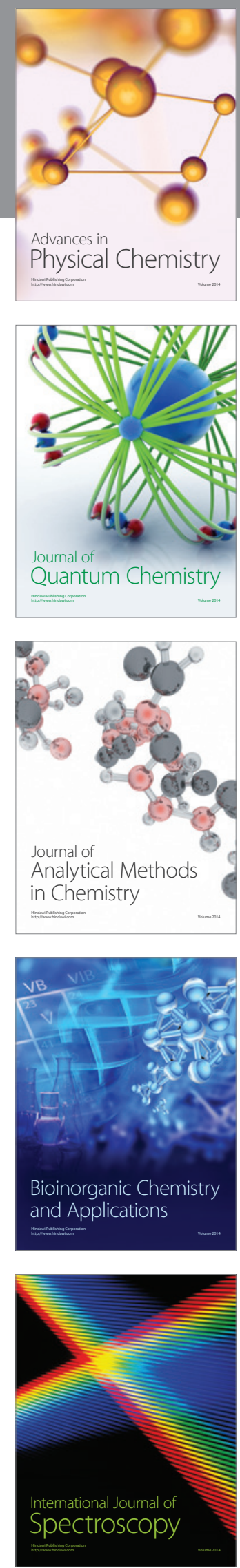